\title{
What is the role of the practice nurse in the care of people living with dementia, or cognitive impairment, and their support person(s)?: a systematic review
}

\author{
Caroline Gibson $^{1^{*}}$ (D), Dianne Goeman ${ }^{1,2}$ and Dimity Pond ${ }^{1}$
}

\begin{abstract}
Background: The potential value of expanding the Practice Nurse role to include the recognition and management of dementia has been acknowledged. Practice Nurses are well-positioned to provide comprehensive dementia information and support so that people living with dementia are better equipped to self-manage their health and live well with dementia. The purpose of this review was to systematically examine published literature to identify existing and potential roles of Practice Nurse's in the delivery of care to people affected by dementia and to describe the characteristics and effectiveness of nurse interventions in dementia models of care.

Methods: The PRISMA statement guided the systematic review of the quantitative and qualitative evidence for roles and characteristics of the Practice Nurse in the delivery of dementia care. A comprehensive literature search of seven electronic databases and Google scholar identified relevant original research published in English between January 2000 and January 2019. Thirteen articles met the inclusion criteria and were extracted into the Covidence software for analysis.

Results: The heterogeneity of the included studies purpose, design and outcomes measures and the diversity in health systems and primary care nurses scope of practice made it difficult to synthesise the findings and draw conclusions. The heterogeneity did, however, provide important insights into the characteristics of roles undertaken by nurses working in the general practice setting, which were potentially beneficial to people living with dementia and their support person. These included patient accessibility to the Practice Nurse, early recognition and management of cognitive changes, care management and collaboration with the General Practitioner. Limitations of the provision of dementia care by Practice Nurses included a lack of definition of the role, inadequate dementia specific training, time constraints and poor communication with General Practitioners.

Conclusions: Embedding an evidence-based model that describes the role of the Practice Nurse in dementia care provision has the potential to increase early recognition of cognitive impairment and more appropriate primary care management of dementia.
\end{abstract}

Systematic review registration: PROSPERO 2018 CRD42018088191.

Keywords: Practice nurse, Primary health care nurse, Dementia, Cognitive impairment

\footnotetext{
* Correspondence: caroline.gibson@uon.edu.au

${ }^{1}$ Faculty of Health and Medicine, School of Medicine and Public Health, University of Newcastle, Callaghan, Australia

Full list of author information is available at the end of the article
}

C C The Author(s). 2020 Open Access This article is licensed under a Creative Commons Attribution 4.0 International License, which permits use, sharing, adaptation, distribution and reproduction in any medium or format, as long as you give appropriate credit to the original author(s) and the source, provide a link to the Creative Commons licence, and indicate if changes were made. The images or other third party material in this article are included in the article's Creative Commons licence, unless indicated otherwise in a credit line to the material. If material is not included in the article's Creative Commons licence and your intended use is not permitted by statutory regulation or exceeds the permitted use, you will need to obtain permission directly from the copyright holder. To view a copy of this licence, visit http://creativecommons.org/licenses/by/4.0/ The Creative Commons Public Domain Dedication waiver (http://creativecommons.org/publicdomain/zero/1.0/) applies to the data made available in this article, unless otherwise stated in a credit line to the data. 


\section{Introduction}

Australian and international literature $[1,2]$ reveals a significant gap in the delivery of dementia care in the general practice setting. In one study, $66 \%$ of participants (people with memory concerns) reported that they would like a memory test and $81 \%$ reported that they would speak with their General Practitioner (GP) if they thought they had dementia [3]. However, despite people's intent to report their concerns with their GP, there is a significant gap in the delivery of dementia care in the general practice setting [1]. Barriers to the identification, diagnosis and management of dementia are multiple and complex, and in some cases include a perception by the GP that nothing can be done and that support options are lacking [4]. Dementia is the second leading cause of death in Australia and currently more than 400000 Australians are living with dementia (5). This number is expected to increase three-fold by 2056 [5]. Around $83 \%$ of all males with dementia and $71 \%$ of females with dementia live in the community [5] with 50 percent of dementia cases remaining undiagnosed [6]. When combining these figures with the approximately 200000 unpaid care-givers involved in supporting a person living with dementia [5] a significant number of people are likely to be attending general practices and not having their health and social care needs met. Exploring new ways to improve the identification and management of dementia in the primary care setting is needed.

Approximately two thirds of Australian general practices employ a nurse [7] and nurse-led clinics are known to maximise patient health outcomes in primary care $[8$, 9]. The Practice Nurse $(\mathrm{PN})$ is a primary health care nurse employed in General Practice. As described by the Australian Primary Health Care Nurse Association (APNA) the role of the PN can include women's health, men's health, aged care, chronic disease management, immunisation, wound management, health promotion and population health. Given that co-morbidity in people living with dementia is high $[8,10]$ the $\mathrm{PN}$ is likely to have established a therapeutic relationship with people with cognitive decline through routine primary care treatment, health assessment, chronic disease management and health promotion activities.

The potential value of expanding the $\mathrm{PN}$ role to include the recognition and management of dementia has been acknowledged $[4,11,12]$. However, there is limited research on the role of the PN in dementia care delivery in Australian or in international literature. A significant barrier to GP's discussing dementia with their patients is the perception that nothing can be done and that support options are lacking [4]. Developing a model of dementia care that incorporates a flexible clinical pathway to guide the $\mathrm{PN}$, along with a compendium of resources that can be used to draw upon additional knowledge to assist in providing appropriate care for people with dementia, could help to overcome these barriers. The PN could offer the GP a means of providing immediate support to patients and their families, following a discussion about dementia that includes a conversation about their concerns and referral on to further supports as needed.

In summary, a PN model of dementia care has the potential to assist with the identification of cognition concerns and understanding of the impact of dementia on the health and well-being of an individual. Such a model is not only likely to lead to increased identification of dementia but also to more appropriate primary care treatment, chronic disease management, and, care planning for people with existing or emerging cognitive impairment or dementia and the people supporting them.

There has been no systematic review of the evidence on the role of the PN in dementia care delivery to date, therefore the aim of this review is to examine published literature to investigate the Practice Nurse role in the delivery of care to people affected by dementia.

This paper systematically reviews published literature to answer the review questions:

1. What are the existing and potential roles performed by the $\mathrm{PN}$ in the care of people living with dementia or cognitive impairment and their informal caregivers in General Practice?

2. What are the characteristics of any existing nurse interventions that provide care to people living with dementia, or cognitive impairment, and their informal caregivers in the General Practice setting?

The 27 item PRISMA-P Checklist [13] was used to guide this systematic review. The checklist includes items deemed essential for systematic review reporting [14].

\section{Methods \\ Eligibility criteria}

All published literature that described a role in care of a person with dementia and/ or their caregiver performed by a nurse in a General Practice setting published between the dates 1 January 2000 and 1 January 2019 were eligible for inclusion. Studies were limited to those published in English language.

\section{Information sources}

A search strategy was developed to identify published peer-reviewed studies describing the role of the PN in the care of people living with dementia, or cognitive impairment, and their informal caregivers in general practice. 
Seven electronic databases (Cochrane Library, EMBASE, CINHAHL (EBSCO), OVID MEDLINE (PubMed), Scopus, INFORMIT HEALTH and PsycINFO) and Google Scholar were searched.

A review of the included paper's reference lists and citations was undertaken to identify any additional studies that may not have been identified in the primary search.

\section{Search strategy}

Original searches were carried out on the $24^{\text {th }}$ February, 2018. Automatic search strategies for all included electronic databases were set up with weekly email alerts to identify eligible studies published from the date of the original search to $1^{\text {st }}$ January 2019. Search terms used included:

1. Practice Nurse, Primary Health Care Nurse , Primary Care Nurse, General Practice Nurse, General Practice Nurse (MeSH Nurse)

2. Dementia, Cognitive impairment, Cognitive deficit, Alzheimer's disease, Memory loss, Vascular dementia, Lewy body dementia, Frontotemporal dementia, Younger onset dementia $(\mathrm{MeSH}$ Dementia) Cognitive impairment, Cognitive deficit, Cognitive decline, Cognitive dysfunction (MeSH Cognitive dysfunction)

Example of a search query Medline

1. (Practice Nurs* or Primary Health Care Nurs* or Primary Care Nurs* or General Practice Nurs* or GP Nurs*).af.

2. (Dementia, or Cognitive impairment or Cognitive dysfunction or cognitive deficit or cognitive decline or alzheimer* or memory impairment or memory loss).af.

\section{Study selection}

All records from searches were retrieved in Endnote reference management software, and transferred to Covidence, the on-line standard production platform for Cochrane Reviews (https://www.covidence.org/home). Using Covidence, all records were independently screened for eligibility using the identified inclusion criteria by two authors (CG and DG). Any discrepancies were resolved by a consensus meeting with the third author (DP).

The steps taken for paper selection were an initial screening for relevance using the titles of identified references. Papers considered to be irrelevant were removed from the selection process. A conservative approach was taken. Abstracts of remaining titles were reviewed based on inclusion criteria. The abstracts were coded relevant, irrelevant or unsure. The irrelevant papers were discarded from the selection process. Published papers were retrieved for abstracts categorised as relevant or unsure. The retrieved papers were then reviewed and those deemed as meeting the selection criteria were included in the systematic review (see Fig. 1).

Where the findings of a study have been published as separate papers due to the reporting of different outcome measures the paper with the most detailed analysis relevant to the aims of this systematic review was included. The other papers adding information to the paper included in this systematic review were described as supplementary papers.

\section{Data Collection processes}

Data extraction for all study types included: author, year, country; aim; research design; instruments; sample and size; intervention type; analysis methods and outcomes. This information is described in Tables 5, 6, 7 and 8.

\section{Quality and risk of bias assessment}

Two reviewers (CG, DG) independently assessed the studies for quality and risk of bias according to their specific study types. Any disagreements between the reviewers were resolved by discussion, with involvement of a third reviewer (DP).

Randomised Controlled Trial (RCT) studies were assessed for risk of bias using the Cochrane Risk of Bias Tool [44]. The CEBM Critical Appraisal tool [45] was used to assess the risk of bias in methodology, analysis and outcomes in cross-sectional studies. Mixed methods data was appraised using the Mixed Methods Appraisal Tool (MMAT) Version 2018 [46]. Risk of bias in qualitative studies was appraised using a tool based on the Critical Appraisal Skills Programme (CASP) Qualitative checklist [47]. The assessment criteria for each of the quality appraisal tools used is described in Tables 1, 2, 3 and 4 .

\section{Synthesis of results}

Synthesis of data from studies so diverse in research questions, methodologies, nurse scope of practice and health systems is inherently problematic and it was not possible to sensibly categorise findings into themes.

In this systematic review a rigorous and transparent method was utilised to organise, describe, explore and interpret the findings and generate new insights $[48,49]$. Eligible studies were selected using the defined inclusion criteria and then categorised into groups according to study design. Quality and risk of bias assessment was carried out according to their specific study types. Following quality assessment, data were extracted from the studies and tabulated under the headings: research aim; study design; instruments; sample characteristics; intervention type; analysis and outcomes. (Tables 5, 6, 7 and 8 ). The data were synthesised according to the three 


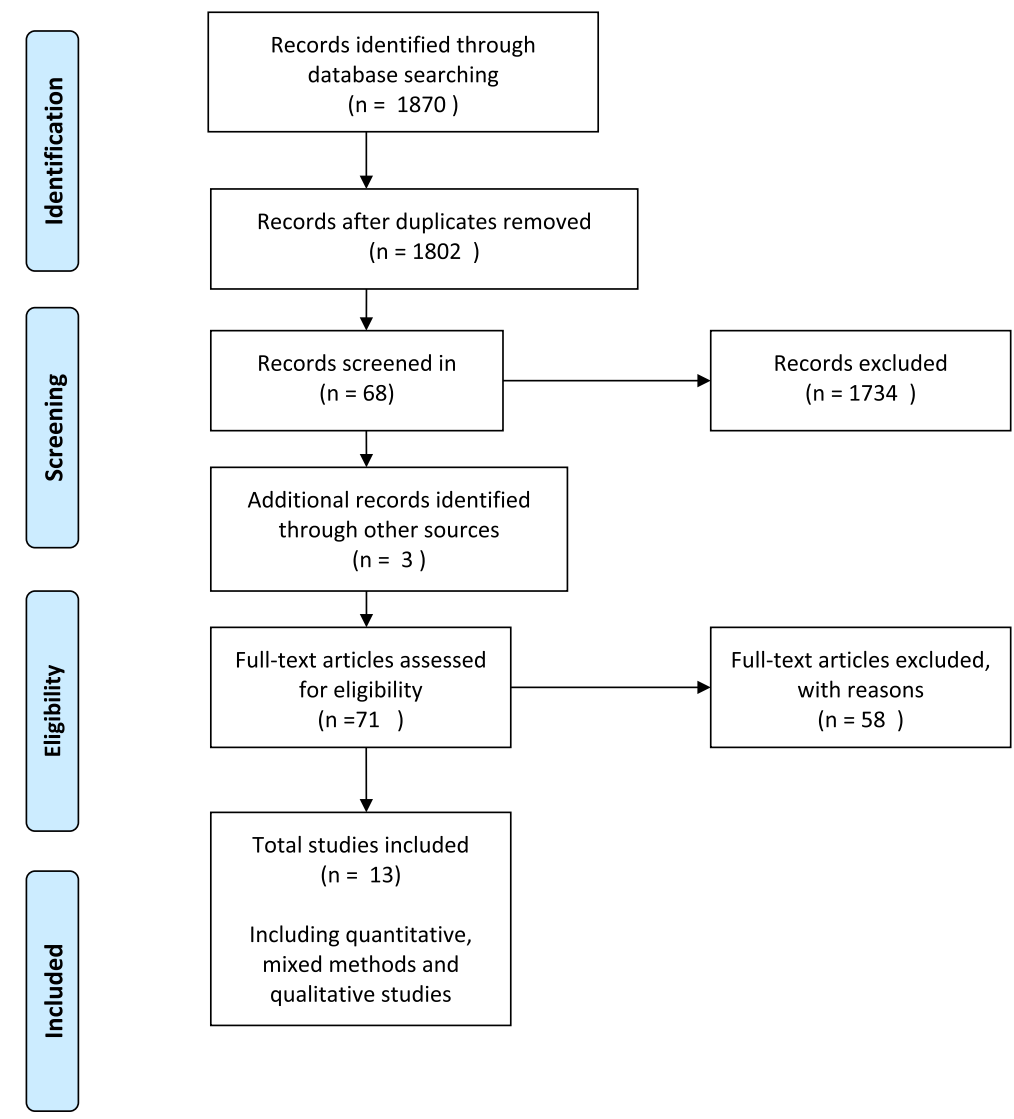

Fig. 1 Study selection

study types; quantitative, qualitative and mixed methods. The three syntheses were then integrated into one synthesis which informed the findings of this systematic review. (Refer Fig. 2).

This approach provided an analysis of the published academic literature and enabled the exploration of relationships within and between studies and a description of themes across the included studies.

\section{Results}

The search strategy identified 1870 references (Fig. 1). After removal of duplicates 1802 abstracts were examined for relevance and 68 full text references were obtained for full text screening. Hand-searching of references lists of included articles yielded an additional three articles. In total 71 articles were assessed for eligibility, of which 13 articles were selected for data extraction and analysis.

Fifty-eight studies assessed for eligibility were excluded. Eighteen were grey literature, 17 did not include the primary health care nurse, six were poster abstracts and the studies not published, and 17 papers were removed as they were multiple publications reporting on the same intervention and were included as supplementary papers. Three were duplicate studies $[18,22,23]$ and two studies $[16,50]$ were excluded as the outcomes

Table 1 Risk of bias summary. Randomised controlled trials. Cochrane Risk of Bias Tool [44]

\begin{tabular}{|c|c|c|c|c|c|c|c|}
\hline & $\begin{array}{l}\text { Random sequence } \\
\text { generation } \\
\text { (selection bias) }\end{array}$ & $\begin{array}{l}\text { Allocation } \\
\text { concealment } \\
\text { (selection bias) }\end{array}$ & $\begin{array}{l}\text { Blinding participants and } \\
\text { personnel for all outcomes } \\
\text { (performance bias) }\end{array}$ & $\begin{array}{l}\text { Blinding of } \\
\text { outcome assessors } \\
\text { for all outcomes }\end{array}$ & $\begin{array}{l}\text { Incomplete outcome } \\
\text { data for all outcomes } \\
\text { (attrition bias) }\end{array}$ & $\begin{array}{l}\text { Selective outcome } \\
\text { reporting } \\
\text { (reporting bias) }\end{array}$ & $\begin{array}{l}\text { Other } \\
\text { sources } \\
\text { of bias }\end{array}$ \\
\hline $\begin{array}{l}\text { Callahan et } \\
\text { al., } 2006 \text { [18] }\end{array}$ & + & + & $?$ & + & + & + & + \\
\hline $\begin{array}{l}\text { Thyrian et al., } \\
2017 \text { [19] }\end{array}$ & + & - & - & - & - & + & + \\
\hline $\begin{array}{l}\text { Van den } \\
\text { Dungen et al., } \\
2016[15]\end{array}$ & + & - & - & $?$ & - & + & + \\
\hline
\end{tabular}

- High risk of bias, + Low risk of bias, ? Unclear risk of bias 
Table 2 Risk of bias summary. Qualitative studies. Based on the CASP Qualitative checklist [47]

\begin{tabular}{lllllllllll}
\hline Criteria & 1 & 2 & 3 & 4 & 5 & 6 & 7 & 8 & 9 & 10 \\
\hline Study & + & + & + & + & + & + & + & + & + & + \\
\hline Dodd et al., 2014 [39] & + & & & & & & & & & \\
Dodd et al., 2016 [41] & + & + & + & + & + & + & + & + & + & + \\
Manthorpe et al., 2003 [12] & + & + & + & + & + & $?$ & ? & + & + & +
\end{tabular}

+ Yes, - No, ? Unsure

Criteria

1. Was there a clear statement of aims?

2. Is a qualitative methodology appropriate?

3. Was the research design appropriate to address the aims of the research?

4. Was the recruitment strategy appropriate to the aims of the research?

5. Was the data collected in a way that addressed the research issue?

6. Has the relationship between the researcher and participants been

adequately considered?

7. Have ethical considerations been taken into consideration?

8. Was the data analysis sufficiently rigorous?

9. Is there a clear statement of findings?

10. Does the research make a contribution to existing knowledge or understanding?

had not been published. The authors of these studies were contacted. Bryans et al., [50] did not publish the outcomes of a survey study on primary health care nurses and dementia care due to significant loss to follow-up. For similar reasons, Perry et al., [16] did not publish the outcomes of the dementia training programme on diagnostic assessment and management of dementia by primary care nurses.

\section{Study characteristics}

Of the 13 included studies, six were quantitative studies: three RCTs and three survey questionnaires, four were mixed-method studies and three were qualitative studies using interviews.

The studies were conducted in the Netherlands $(n=1)$, Germany $(n=1)$, United States of America $(n=1)$, The United Kingdom ( $n=5)$, Australia $(n=4)$ and one

Table 3 Risk of bias summary. Mixed Methods studies. Mixed Methods Appraisal Tool (MMAT) Version 2018 [46]

\begin{tabular}{llllll}
\hline Criteria & 1 & 2 & 3 & 4 & 5 \\
\hline Studies & + & + & + & + & + \\
\hline lliffe et al., 2014 [35] & + & + & + & NA & - \\
Millard et al., 2011 [3] & - & - & + & $?$ & - \\
Ollerenshaw et al., 2017 [32] & + & + & + & + & + \\
Perry et al., 2010 [34] & + & & & & +
\end{tabular}

+ Yes, - No, ? Can't tell

Criteria questions

1. Is there an adequate rationale for using a mixed methods design to address the research question?

2. Are the different components of the study effectively integrated to answer the research question?

3. Are the outputs of the integration of qualitative and quantitative components adequately interpreted?

4. Are the divergences and inconsistencies between qualitative and quantitative results adequately addressed?

5. Do the different components of the study adhere to the quality criteria of each tradition of the methods involved?
Table 4 Risk of bias summary. Survey studies. Critical Appraisal of a Survey checklist [45]

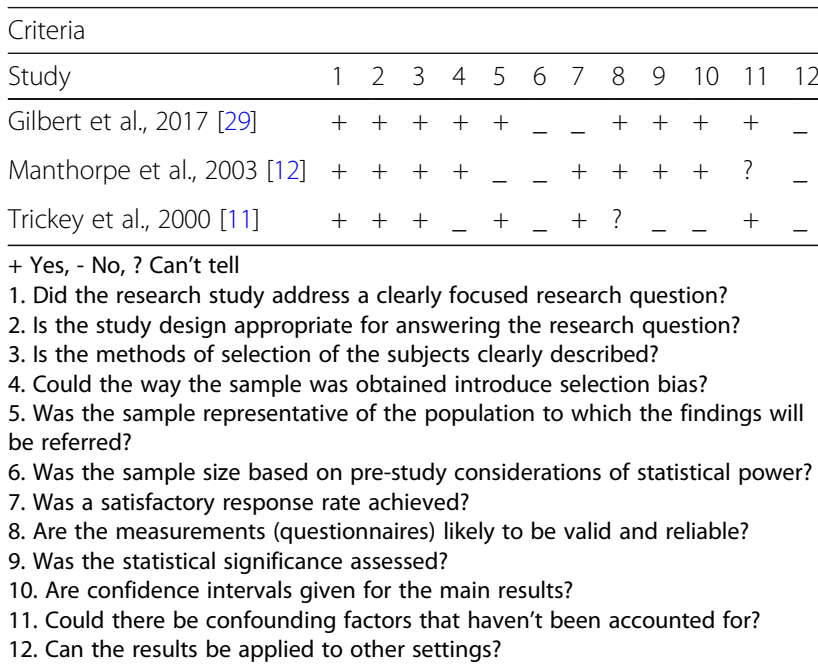

was conducted across the Netherlands and the United Kingdom $(\mathrm{n}=1)$.

Four studies $[15,18,19,35]$ evaluated dementia care management in primary health care. Exploring dementia care knowledge and attitudes of primary health care practitioners was the focus of three studies $[3,11,12]$. Two studies [39, 41] explored participant experiences of dementia care delivery in primary health care and one study [29] explored service use and reported unmet needs of people with dementia and support person(s). Investigating the implications of early recognition of dementia for the roles of the primary health care team was the focus of one study [43] The authors of one study [34] developed quality indicators for dementia care in primary health care settings and one study investigated the value and useability of an online dementia management tool for health professionals [32]. The study interventions and outcomes are described in Tables 5, 6, 7 and 8 .

\section{Quantitative Studies}

Randomised Controlled Trials Three studies utilised an RCT $[15,18,19]$ to investigate the impact of collaborative care on quality of life for people with dementia and their caregivers. The study by Van den Dungen et al., [15] also included an evaluation of family practitioner training on diagnosis of mild cognitive impairment.

In all three models of care the nurse was the care manager who worked in collaboration with the primary care doctor. All care management models followed a structured assessment and care planning protocol. Care management ranged in duration from six [19] to twelve months $[15,18]$. In two studies $[15,19]$ the care managers were registered nurses, with Van den Dungen et al., [15] specifying the nurse as a primary care nurse 
Table 5 Quantitative studies. Characteristics of the Randomised Controlled Trials reviewed

\begin{tabular}{|c|c|c|c|c|c|c|c|}
\hline $\begin{array}{l}\text { Author, year, } \\
\text { country }\end{array}$ & Aim & $\begin{array}{l}\text { Research } \\
\text { design }\end{array}$ & Instruments & $\begin{array}{l}\text { Sample and size } \\
\text { (+characteristics) }\end{array}$ & $\begin{array}{l}\text { Type and } \\
\text { description of } \\
\text { intervention }\end{array}$ & $\begin{array}{l}\text { Analysis } \\
\text { method }\end{array}$ & Outcomes \\
\hline $\begin{array}{l}\text { Van den } \\
\text { Dungen et al., } \\
2016 \text { [15] } \\
\text { The } \\
\text { Netherlands, } \\
\text { United } \\
\text { Kingdom } \\
\text { Supplementary } \\
\text { papers: } \\
\text { Perry et al., } \\
2008 \text { [16] } \\
\text { Van den } \\
\text { Dungen et al., } \\
2012 \text { [17] }\end{array}$ & $\begin{array}{l}\text { To assess the } \\
\text { effect of a two- } \\
\text { component } \\
\text { intervention of } \\
\text { case finding and } \\
\text { subsequent care } \\
\text { on diagnostic } \\
\text { yield of case } \\
\text { finding and its } \\
\text { impact on the } \\
\text { mental health of } \\
\text { patients and } \\
\text { relatives. }\end{array}$ & $\begin{array}{l}\text { Cluster } \\
\text { randomised } \\
\text { controlled } \\
\text { trial with } \\
\text { process } \\
\text { evaluation }\end{array}$ & $\begin{array}{l}\text { Cambridge } \\
\text { Cognition } \\
\text { Examination } \\
\text { (CAMCOG) } \\
\text { Quality of Life- } \\
\text { Alzheimer's } \\
\text { Disease (QoL- } \\
\text { AD) } \\
\text { Mental Health } \\
\text { part of SF-36 } \\
\text { (MH5) } \\
\text { Short form } \\
\text { health survey } \\
\text { (SF36) } \\
\text { MDS } \\
\text { Euro-Qol (EQ5D) } \\
\text { 12-item General } \\
\text { Health } \\
\text { Questionnaire } \\
\text { (GHQ12) } \\
\text { Short sense of } \\
\text { Competence } \\
\text { Questionnaire } \\
\text { (SSCQ) } \\
\text { Neuropsychiatric } \\
\text { Inventory (NPI) } \\
\text { 12-item Social } \\
\text { Support List } \\
\text { (SSL12) } \\
\text { 15-item Katz } \\
\text { questionnaire } \\
\text { (Katz15) } \\
\text { Mini Mental } \\
\text { State } \\
\text { Examination } \\
\text { (MMSE) }\end{array}$ & $\begin{array}{l}162 \text { participants } \geq \\
65 \text { years in } 15 \\
\text { primary care } \\
\text { practices in whom } \\
\text { Family } \\
\text { Practitioners ( } \mathrm{n}= \\
\text { 29) suspect } \\
\text { cognitive } \\
\text { impairment, but } \\
\text { without a } \\
\text { dementia } \\
\text { diagnosis } \\
2 \text { PNs over } 7 \\
\text { intervention } \\
\text { practices }\end{array}$ & $\begin{array}{l}\text { Intervention 1: } \\
\text { Family } \\
\text { practitioners (FP) } \\
\text { attended } 5 \text { hours } \\
\text { of dementia } \\
\text { education. } \\
\text { Education content } \\
\text { based on the } \\
\text { EASYcare } \\
\text { dementia training } \\
\text { program } \\
\text { described in Perry } \\
\text { et al., [18] } \\
\text { Intervention 2. In } \\
\text { addition to above, } \\
\text { case finding of } \\
\text { MCl and dementia } \\
\text { and collaborative } \\
\text { care by a } \\
\text { dementia trained } \\
\text { PN (a Registered } \\
\text { Nurse) and the FP. } \\
\text { Nurse assessment } \\
\text { and care planning } \\
\text { was based on the } \\
\text { outcomes of the } \\
\text { Residential } \\
\text { Assessment } \\
\text { Instrument (RAI). }\end{array}$ & $\begin{array}{l}\text { Generalised } \\
\text { Estimating } \\
\text { Equations } \\
\text { (GEE) analysis } \\
\text { Odds Ratio, } \\
\text { 95\% } \\
\text { confidence } \\
\text { interval }\end{array}$ & $\begin{array}{l}\text { Training FPs } \\
\text { resulted in a non- } \\
\text { significant } \\
\text { increase in the } \\
\text { number of new } \\
\text { MCl diagnosis. } \\
\text { There were no } \\
\text { differences in } \\
\text { mental health } \\
\text { (QOL measure) } \\
\text { between the } \\
\text { group receiving } \\
\text { collaborative care } \\
\text { and the control } \\
\text { group. } \\
\text { FPs and PNs } \\
\text { found care } \\
\text { management to } \\
\text { be a positive } \\
\text { experience, } \\
\text { although the } \\
\text { nurses it to be } \\
\text { time consuming. } \\
\text { Further study of } \\
\text { collaboration } \\
\text { between FP and } \\
\text { PNs is } \\
\text { recommended. }\end{array}$ \\
\hline $\begin{array}{l}\text { Thyrian, J.R.et } \\
\text { al., 2017 [19] } \\
\text { Germany. } \\
\text { Supplementary } \\
\text { papers: } \\
\text { Dreier et al., } \\
2016 \text { [20] } \\
\text { Thyrian et al., } \\
2013 \text { [21]. }\end{array}$ & $\begin{array}{l}\text { To test the } \\
\text { effectiveness and } \\
\text { safety of Dementia } \\
\text { Care management } \\
\text { (DCM) in the } \\
\text { treatment and } \\
\text { care of people } \\
\text { with dementia } \\
\text { living at home } \\
\text { and caregiver } \\
\text { burden (when } \\
\text { available) }\end{array}$ & $\begin{array}{l}\text { Cluster- } \\
\text { randomised } \\
\text { intervention } \\
\text { trial }\end{array}$ & $\begin{array}{l}\text { Quality of Life } \\
\text { (QoL-AD score) } \\
\text { Neuropsychiatric } \\
\text { symptoms (NPI } \\
\text { score) } \\
\text { Caregiver burden } \\
\text { (BIZA-D score) } \\
\text { Anti-dementia } \\
\text { drug treatment } \\
\text { Potentially } \\
\text { inappropriate } \\
\text { medication } \\
\text { prescription }\end{array}$ & $\begin{array}{l}634 \text { people } \\
\text { diagnosed as } \\
\text { having dementia } \\
407 \text { received the } \\
\text { intervention }\end{array}$ & $\begin{array}{l}\text { DCM Is a model of } \\
\text { collaborative care } \\
\text { aimed at } \\
\text { providing optimal } \\
\text { care for patients } \\
\text { with dementia } \\
\text { and support care- } \\
\text { givers. DCM uses a } \\
\text { computer-assisted } \\
\text { assessment } \\
\text { determining a } \\
\text { personalised array } \\
\text { of intervention } \\
\text { modules and } \\
\text { monitoring. } \\
\text { DCM was } \\
\text { provided by a } \\
\text { dementia trained } \\
\text { RN for } 6 \text { months } \\
\text { in the home } \\
\text { according to a } \\
\text { systematic, } \\
\text { detailed protocol. } \\
\text { The nurses } \\
\text { completed an } \\
\text { intensive training } \\
\text { program } \\
\text { described in Drier } \\
\text { et al. [21]. }\end{array}$ & $\begin{array}{l}\text { Descriptive } \\
\text { statistics } \\
\text { - Means, SD } \\
\text { - Proportions } \\
\text { Primary } \\
\text { analysis } \\
\text { - } \\
\text { Generalised } \\
\text { regression } \\
\text { models } \\
\text { Secondary } \\
\text { analysis } \\
\text { - } \\
\text { Stratification } \\
\text { of the } \\
\text { models by } \\
\text { patient's } \\
\text { living } \\
\text { situation }\end{array}$ & $\begin{array}{l}\text { A significant } \\
\text { decrease in } \\
\text { patient's } \\
\text { behavioural and } \\
\text { psychological } \\
\text { symptoms of } \\
\text { dementia and } \\
\text { caregiver burden } \\
\text { was reported. } \\
\text { There was a } \\
\text { significant } \\
\text { increase in quality } \\
\text { of life for patients } \\
\text { not living alone, } \\
\text { but no } \\
\text { improvement in } \\
\text { quality of life } \\
\text { overall. } \\
\text { No significant } \\
\text { effect on patient's } \\
\text { cognitive status, } \\
\text { daily living } \\
\text { activities, or } \\
\text { institutionalisation } \\
\text { was found. }\end{array}$ \\
\hline
\end{tabular}


Table 5 Quantitative studies. Characteristics of the Randomised Controlled Trials reviewed (Continued)

\begin{tabular}{|c|c|c|c|c|c|c|c|}
\hline $\begin{array}{l}\text { Author, year, } \\
\text { country }\end{array}$ & Aim & $\begin{array}{l}\text { Research } \\
\text { design }\end{array}$ & Instruments & $\begin{array}{l}\text { Sample and size } \\
\text { (+characteristics) }\end{array}$ & $\begin{array}{l}\text { Type and } \\
\text { description of } \\
\text { intervention }\end{array}$ & $\begin{array}{l}\text { Analysis } \\
\text { method }\end{array}$ & Outcomes \\
\hline $\begin{array}{l}\text { Callahan et al., } \\
2006 \text { [18] } \\
\text { United States } \\
\text { Supporting } \\
\text { papers } \\
\text { Austrom et al., } \\
2005 \text { [22] } \\
\text { Austrom et al., } \\
2006 \text { [23] } \\
\text { Austrom et al., } \\
2004 \text { [24] } \\
\text { Boustani et al., } \\
2005 \text { [25] }\end{array}$ & $\begin{array}{l}\text { To test the } \\
\text { effectiveness of a } \\
\text { collaborative care } \\
\text { model to improve } \\
\text { the quality of care } \\
\text { for patients with } \\
\text { Alzheimer's } \\
\text { disease. }\end{array}$ & $\begin{array}{l}\text { Randomised } \\
\text { Controlled } \\
\text { Trial }\end{array}$ & $\begin{array}{l}\text { Total patient } \\
\text { Neuropsychiatric } \\
\text { Inventory (NPI) } \\
\text { Total caregiver } \\
\text { Neuropsychiatric } \\
\text { Inventory (NPI) } \\
\text { Cornell Scale for } \\
\text { Depression in } \\
\text { Dementia } \\
\text { (CSDD) } \\
\text { Telephone } \\
\text { Interview for } \\
\text { Cognitive Status } \\
\text { Patient Health } \\
\text { Questionnaire- } \\
\text { Alzheimer } \\
\text { Disease } \\
\text { Cooperative } \\
\text { Study Group } \\
\text { ADLS } \\
\text { Caregiver Patient } \\
\text { Health } \\
\text { Questionnaire-9 }\end{array}$ & $\begin{array}{l}153 \\
\text { predominantly } \\
\text { ethnic older adults } \\
\text { with Alzheimer } \\
\text { Disease and their } \\
\text { care-givers } \\
84 \text { people } \\
\text { received the } \\
\text { intervention of } \\
\text { collaborative care } \\
\text { management } \\
\text { The settings were } \\
\text { large primary care } \\
\text { practices, } \\
\text { community-based } \\
\text { health centres and } \\
\text { a Veteran Affairs } \\
\text { Medical Centre. }\end{array}$ & $\begin{array}{l}12 \text { months of care } \\
\text { management } \\
\text { using current } \\
\text { Alzheimer's } \\
\text { Disease treatment } \\
\text { guidelines } \\
\text { Delivered by a FP } \\
\text { and an advanced } \\
\text { PN (geriatric nurse } \\
\text { practitioner) acting } \\
\text { as the care } \\
\text { manager } \\
\text { Care-givers and } \\
\text { patients were seen } \\
\text { by the nurse } \\
\text { fortnightly and } \\
\text { then monthly for } \\
\text { period of } 1 \text { year } \\
\text { There were } 4 \\
\text { intervention } \\
\text { components } \\
\text { 1. A behavioural } \\
\text { intervention } \\
\text { protocol } \\
\text { (described in } \\
\text { Austrom et al., } \\
\text { [24], Boustani et } \\
\text { al.,[25] } \\
\text { 2. Weekly Care } \\
\text { manager support } \\
\text { meetings } \\
\text { 3. A web-based } \\
\text { longitudinal } \\
\text { tracking system } \\
\text { 4. voluntary group } \\
\text { care-giver sessions } \\
\text { for care-givers } \\
\text { with a group } \\
\text { exercise group for } \\
\text { patients }\end{array}$ & $\begin{array}{l}\text { 2-tailed a level } \\
\text { of } 0.05 \\
2 \text {-sample } t \\
\text { tests } \\
X^{2} \text { tests } \\
\text { Mixed-effects } \\
\text { regression } \\
\text { Kaplan-Meier } \\
\text { estimation } \\
\text { Wilcoxon test }\end{array}$ & $\begin{array}{l}\text { Patients } \\
\text { experienced } \\
\text { significant } \\
\text { improvements in } \\
\text { total NPI scores } \\
\text { which continued } \\
\text { beyond the } 12 \\
\text { month } \\
\text { intervention } \\
\text { The intervention } \\
\text { had no significant } \\
\text { impact on patient } \\
\text { depression scores, } \\
\text { cognition or } \\
\text { function. } \\
\text { There were } \\
\text { significant } \\
\text { improvements in } \\
\text { caregiver stress at } \\
12 \text { months but } \\
\text { not at } 18 \text { months. } \\
\text { There was no } \\
\text { difference in } \\
\text { cumulative } \\
\text { hospitalisation } \\
\text { rates, mean } \\
\text { hospital days or } \\
\text { rates of nursing } \\
\text { home placement }\end{array}$ \\
\hline
\end{tabular}

who acted as the study nurse. In the third study [18] the care manager was a geriatric nurse practitioner. All the nurses received dementia specific training and were integrated into the primary care team with only one care manager providing the dementia care management within the patients' home [19]. In addition to training, in the model of care described in Callahan et al., [18] the nurse received weekly support from a geriatrician, geriatric psychiatrist and a psychologist.

Callahan et al., [18] and Thyrian et al., [19] reported a significant decrease in behavioural and psychological symptoms of dementia and caregiver stress with dementia care management, however, Thyrian et al., [19] reported there was no significant improvement in quality of life overall. Despite reporting that dementia care management had no impact on quality of life measures for patients or their care-givers, Van den Dungen et al.,[15] recommend that collaborative care with nurses in primary care deserves further exploration.
Survey Questionnaire studies Three studies reported survey results [11, 12, 29]. Manthorpe et al., [12] and Trickey et al., [11] investigated dementia knowledge and attitudes of community nurses $(\mathrm{CN})$, health visitors, community mental health care nurses $(\mathrm{CMHN})$ and $\mathrm{PNs}$ in the provision of care for people living with dementia. The third study [29] explored service use and unmet needs of people with dementia recruited a decade apart.

Manthorpe et al., [12] reported all groups of primary health care nurses had similar knowledge related to the early signs and symptoms of dementia. However, PNs were less confident in providing advice and support than CMHNs. In the study undertaken by Trickey et al., [11], PNs completing the Over-75 year health check were less likely than other nurse groups to take any action, other than to refer to the GP, when presented with a person living with dementia and their support person. The Over-75 year health check is an annual health check including a mental assessment for people aged over 75 years [11]. 
Table 6 Quantitative studies. Characteristics of the Survey/ Questionnaire studies reviewed

\begin{tabular}{|c|c|c|c|c|c|c|c|}
\hline $\begin{array}{l}\text { Author, year, } \\
\text { country }\end{array}$ & Aim & $\begin{array}{l}\text { Research } \\
\text { design }\end{array}$ & Instruments & $\begin{array}{l}\text { Sample and size } \\
\text { (characteristics) }\end{array}$ & $\begin{array}{l}\text { Type and } \\
\text { description } \\
\text { of } \\
\text { intervention }\end{array}$ & $\begin{array}{l}\text { Analysis } \\
\text { method }\end{array}$ & Outcomes \\
\hline $\begin{array}{l}\text { Trickey et al., } \\
2000[11] \\
\text { United } \\
\text { Kingdom }\end{array}$ & $\begin{array}{l}\text { To examine the } \\
\text { knowledge and attitudes } \\
\text { of primary care nurses } \\
\text { who undertake the } \\
\text { Over-75 Check, towards } \\
\text { assessing and managing } \\
\text { patients with symptoms } \\
\text { of dementia, and to } \\
\text { assess their level of } \\
\text { support for a clinical } \\
\text { practice guideline. }\end{array}$ & Descriptive & $\begin{array}{l}\text { Postal questionnaire } \\
\text { survey of primary care } \\
\text { nurses responsible for the } \\
\text { Over-75 Check } \\
\text { Questionnaire included } \\
\text {-a case vignette for } \\
\text { eliciting information } \\
\text { about knowledge, } \\
\text { attitudes and opinions } \\
\text {-demographic } \\
\text { information }\end{array}$ & $\begin{array}{l}127 \text { (65\% response } \\
\text { rate) respondents } \\
-71 \% \text { practice based } \\
\text { nurses } \\
-11 \% \text { health visitors } \\
-6 \% \text { district nurses } \\
-12 \% \text { other } \\
\text { All respondents were } \\
\text { female } \\
75 \% \text { over } 40 \text { years } \\
32 \% \text { over } 50 \text { years } \\
18 \% \text { had completed a } \\
\text { post-registration } \\
\text { course in nursing older } \\
\text { people }\end{array}$ & & $\begin{array}{l}\text { Analyses } \\
\text { using SPSS } \\
6.0 \text { and the } \\
\text { commands } \\
\text { 'descriptives' } \\
\text { and } \\
\text { 'crosstabs" }\end{array}$ & $\begin{array}{l}\text { In response to the } \\
\text { vignette } \\
\text { PN were less likely to take } \\
\text { any action themselves } \\
\text { than were other } \\
\text { professionals (61 vs 78\%) } \\
\text { (just failed to reach } \\
\text { statistical significance } \\
\text { (chi-squared test P=0.07) } \\
\text { Thematic analysis of the } \\
\text { vignettes revealed that } \\
\text { the nature of the referral } \\
\text { to the GP was influenced } \\
\text { by the respondent's } \\
\text { knowledge of dementia, } \\
\text { understanding own } \\
\text { professional role and by } \\
\text { structural constraints such } \\
\text { as the need to use the } \\
\text { GP to access other } \\
\text { services. } \\
\text { It was reported that many } \\
\text { professionals undertaking } \\
\text { the Over-75 Check are } \\
\text { not sufficiently well } \\
\text { trained to assess patients } \\
\text { who may be displaying } \\
\text { signs of cognitive } \\
\text { impairment } \\
68 \% \text { of respondents } \\
\text { indicated that new } \\
\text { guidelines would } \\
\text { 'definitely help' them in } \\
\text { their practice. }\end{array}$ \\
\hline
\end{tabular}

\begin{tabular}{|c|c|c|c|}
\hline $\begin{array}{l}\text { Manthorpe et } \\
\text { al., } 2003 \text { [12] } \\
\text { United } \\
\text { Kingdom } \\
\text { Supplementary } \\
\text { papers } \\
\text { Downs \& Rae, } \\
1996 \text { [26] } \\
\text { lliffe et al., } 1999 \\
\text { [27] } \\
\text { Illife et al., } 2003 \\
\text { [28] }\end{array}$ & $\begin{array}{l}\text { To explore whether } \\
\text { Community Mental } \\
\text { Health Nurses (CMHNs ), } \\
\text { Community Nurses } \\
\text { (CNs), and PNs have } \\
\text { different perspectives on } \\
\text { early diagnosis of } \\
\text { dementia }\end{array}$ & $\begin{array}{l}\text { Intervention } \\
\text { Comparative }\end{array}$ & $\begin{array}{l}\text { Questionnaire derived } \\
\text { from the Stirling Service } \\
\text { Development Centre } \\
\text { asked the nurses about } \\
\text { clinical role, experience, } \\
\text { case load, } \\
\text { epidemiological and } \\
\text { clinical knowledge, } \\
\text { confidence in recognising } \\
\text { the dementias and } \\
\text { perceived difficulties in } \\
\text { providing care for people } \\
\text { with dementia }\end{array}$ \\
\hline
\end{tabular}

268 nurses (79 CMHNs,

\begin{tabular}{|c|c|c|}
\hline $\begin{array}{l}1 \text { day } \\
\text { educational } \\
\text { workshop } \\
\text { on } \\
\text { recognition } \\
\text { of and } \\
\text { response to } \\
\text { dementia }\end{array}$ & $\begin{array}{l}\text { Data was } \\
\text { aggregated } \\
\text { by } \\
\text { professional } \\
\text { discipline } \\
95 \% \\
\text { confidence } \\
\text { intervals } \\
1.96 \times \sqrt{ }(p \times \\
9 / n) \\
P \text { proportion } \\
\text { showing the } \\
\text { characteristic } \\
Q \text { proportion } \\
\text { not showing } \\
\text { the } \\
\text { characteristic } \\
n \text { is the } \\
\text { sample size }\end{array}$ & $\begin{array}{l}\text { All three nurse disciplines } \\
\text { reported experience of } \\
\text { working with people with } \\
\text { dementia and had similar } \\
\text { knowledge related the } \\
\text { early signs and symptoms } \\
\text { of dementia. However } \\
\text { CMHNs were more } \\
\text { confident in their } \\
\text { diagnostic skills, ability to } \\
\text { communicate a diagnosis, } \\
\text { provide advice and } \\
\text { obtain support services. } \\
\text { CMHNs considered they } \\
\text { were best placed to } \\
\text { coordinate services for } \\
\text { people with newly } \\
\text { diagnosed dementia and } \\
\text { found providing support } \\
\text { less difficult than CNs and } \\
\text { PNS. } \\
\text { Dementia support in the } \\
\text { community was seen as a } \\
\text { specialist function, with } \\
\text { the key worker role best } \\
\text { fulfilled by CMHNs. }\end{array}$ \\
\hline & $\begin{array}{l}\text { Summary } \\
\text { descriptive } \\
\text { statistics } \\
\text { One-tail chi- } \\
\text { square } \\
\text { Fisher-exact } \\
\text { analysis } \\
\text { Logistic } \\
\text { regression } \\
\text { Binary linear } \\
\text { regression } \\
\text { analysis }\end{array}$ & $\begin{array}{l}\text { There were significantly } \\
\text { more support person(s) } \\
\text { who contacted PNs about } \\
\text { the person with dementia } \\
\text { in the later sample than } \\
\text { the earlier ( } 53.6 \% \\
\text { compared with } 36.9 \%, p= \\
0.01 \text { ) and less evident use } \\
\text { of CNs, psychiatric nurses } \\
\text { and health visitors. PN } \\
\text { use was associated with } \\
\text { having a non-spouse } \\
\text { support person(s) ( } \mathrm{p}=\end{array}$ \\
\hline
\end{tabular}


Table 6 Quantitative studies. Characteristics of the Survey/ Questionnaire studies reviewed (Continued)

\begin{tabular}{|c|c|c|c|c|c|c|c|}
\hline $\begin{array}{l}\text { Author, year, } \\
\text { country }\end{array}$ & Aim & $\begin{array}{l}\text { Research } \\
\text { design }\end{array}$ & Instruments & $\begin{array}{l}\text { Sample and size } \\
\text { (characteristics) }\end{array}$ & $\begin{array}{l}\text { Type and } \\
\text { description } \\
\text { of } \\
\text { intervention }\end{array}$ & $\begin{array}{l}\text { Analysis } \\
\text { method }\end{array}$ & Outcomes \\
\hline & & & & $\begin{array}{l}\text { London } \\
2000-2001 \\
\text { Support person(s) = } \\
122 \\
\text { Sample } 2 \\
\text { South-East England } \\
\text { 2010-2011 } \\
\text { Support person(s) }=84\end{array}$ & & & $\begin{array}{l}\text { 0.022) but no other } \\
\text { factors were significant. } \\
\text { Those who received PN } \\
\text { help generally found it } \\
\text { useful. } \\
\text { Support person(s)s in the } \\
\text { second sample reported } \\
\text { that approximate one } \\
\text { third of people with } \\
\text { dementia were still not } \\
\text { getting the support they } \\
\text { needed and the majority } \\
\text { of support person(s)s } \\
\text { reporting behavioural and } \\
\text { psychological problems } \\
\text { had had no advice on } \\
\text { how to manage this }\end{array}$ \\
\hline
\end{tabular}

Gilbert et al., [29] reported that support person(s) were increasingly contacting a PN for support with less evident use of CNs, health visitors and CMHNs. This may in part be attributed to greater access to a $\mathrm{PN}$ and the changing nature of the PN role with an increased focus on chronic disease management. Support person(s) reported that they were still not getting the advice and support they needed.

Authors of all three studies identified a need to improve PN knowledge of dementia and its management. In the study by Trickey et al., [11] participants reported guidelines would be helpful to address gaps in knowledge and to standardise practice.

\section{Mixed method studies}

Four studies reported mixed-methods research results [3, 32, 34, 35].

Perry et al., [34] used a RAND modified Delphi method to construct a set of quality indicators for dementia diagnosis and management in primary care in the Netherlands. PNs were involved in the selection and validation process of the quality indicators. Of the final 23 quality indicators, two explicitly describe collaboration between the GP and the PN, an area in which the authors suggest improvement is highly recommended. A further three quality indicators emphasise the importance of developing and reviewing individualised care plans. This is commonly a PN role that is established and accepted in primary care settings [34]. Millard et al., [3] explored dementia literacy in a general practice setting. In this study two-thirds of the PNs reported a lack of dementia training. Despite this self-perceived lack of training, three-quarters of the PNs reported that the primary care doctor or nurse was the appropriate person to discuss dementia with patients. Ollerenshaw et al., [32] suggest that PNs may find an on-line dementia management support tool useful. Iliffe et al., [35] adapted a US model of primary care based care management
(PREVENT) for people with dementia and tested its implementation in UK general practice. Despite case managers, patients and support person(s) reporting a positive experience and perceiving benefits of case management, Iliffe et al., [35] suggest that case management does not fit easily into practice routines and that it was not substantially beneficial for patients and support person(s).

\section{Qualitative studies}

All three qualitative studies [39, 41, 43] used interviews to explore experiences of primary health care practitioners, patients and support person(s), of dementia care. Dodd et al., [39] used semi-structured face-to-face interviews to contrast study participants' experiences of a new primary care led dementia service with existing secondary care based memory services in Bristol, UK. Dodd et al., [41] used a semi-structured face-to-face interview to investigate participant's experiences of a new primary care led dementia service in South Gloustershire, UK. In both these studies $[39,41]$ the nurses were seconded from secondary care dementia services, with each nurse working with a group of primary health care clinics. Patients and support person(s) reported primary care led services to be positive and there was uniform praise for the work by the memory nurse. GPs reported they valued the advisory role provided by the memory nurse. Manthorpe et al., [43] explored implications of the early recognition of dementia for inter-professional working using focus group interviews. In this study the PN was identified as the practitioner most appropriate to take on screening for dementia and monitoring, however community mental health care nurses were considered to have the skills and capacity to take on long-term and complex cases.

Risk of bias The methodological quality varied across the studies (Tables 1, 2, 3 and 4). The qualitative studies 
Table 7 Mixed Method studies. Characteristics of Mixed Methods studies reviewed

\begin{tabular}{|c|c|c|c|c|}
\hline $\begin{array}{l}\text { Author, year, } \\
\text { country }\end{array}$ & Aim & Research design & Instruments & $\begin{array}{l}\text { Sample and size } \\
\text { (+characteristics) }\end{array}$ \\
\hline $\begin{array}{l}\text { Ollerernshaw et } \\
\text { al, } 2017 \text { [32] } \\
\text { Australia }\end{array}$ & $\begin{array}{l}\text { To explore the } \\
\text { awareness and } \\
\text { usage of an } \\
\text { online Dementia } \\
\text { Pathways Tool } \\
\text { (DPT) for primary } \\
\text { health care } \\
\text { practitioners in }\end{array}$ & Descriptive & $\begin{array}{l}\text { On-line } \\
\text { questionnaire } \\
\text { Google } \\
\text { Analytics } \\
\text { provides } \\
\text { information on } \\
\text { the usage of } \\
\text { on-line tools. }\end{array}$ & $\begin{array}{l}\text { A total of } 21 \text { GPs } \\
\text { and } 21 \text { PNs } \\
\text { participated in the } \\
\text { study. All the GPs } \\
\text { and PNs worked in } \\
\text { practices located } \\
\text { in regional western } \\
\text { Victoria. }\end{array}$ \\
\hline
\end{tabular}

\begin{tabular}{|c|c|}
\hline $\begin{array}{l}\text { Type and } \\
\text { description of } \\
\text { intervention }\end{array}$ & $\begin{array}{l}\text { Analysis } \\
\text { method }\end{array}$ \\
\hline
\end{tabular}

regional Victoria

$\begin{array}{ll}\text { Millard et al., } & \text { To explore } \\ \text { 2011 [3] } & \text { dementia literacy } \\ \text { Australia } & \text { in a general } \\ \text { Supplementary } & \text { practice setting } \\ \text { paper } & \text { and to test } \\ \text { Millard \& } & \text { whether a } \\ \text { Baune, 2009 } & \text { waiting room } \\ \text { [33] } & \text { pamphlet would } \\ & \text { improve patient } \\ & \text { awareness of } \\ & \text { dementia risk } \\ & \text { reduction }\end{array}$

Mixed method

study:

questionnaire

$\mathrm{RCT}$ and data

from

computerised

medical records for GP/ PN

Questionnaire

for waiting

room patients

Computerised

medical

records.
558 patients $(36 \%$

male

$64 \%$ female;

median age 50-59

years) were

sampled from 22

practices in 14

locations in

Australia

63 patients $(43 \%$

male; $57 \%$ female;

median age of 70 -

79 years) were

sampled from 3

practices in

England.

106 GPs (57 males;

49 female) were

recruited from 50

different sites in

Australia and 21

GPs (9 male; 12

female) were in

England.

26 PNs were

recruited to the

study in total. All

were female and

25 were located in

practices in

Australia and 1 in

England.
Alzheimer's

Australia 'Mind

your Mind"

dementia risk

reduction

pamphlet on

patient

knowledge of

dementia risk

strategies

Patients, aged

over 30 years, in

the waiting room

were

administered a

questionnaire

exploring

dementia and risk

reduction

knowledge. The

intervention, a risk

reduction

education

pamphlet, were

administered to

the patients using

simple

randomisation with $50 \%$ of the

participants

receiving the

pamphlet with

questionnaire and

$50 \%$ receiving the

questionnaire

only.

\author{
Descriptive Of the \\ analysis respondents two \\ thirds were aware \\ of the DPT, with \\ one third having \\ used it. Of those \\ who had used it \\ the majority \\ (92.9\%) found it \\ useful in assisting \\ them in accessing \\ diagnosis, \\ management and \\ referral \\ information. \\ Over an 18 month \\ time period from \\ the launch of the \\ DPT, Google \\ Analytics showed \\ an average of 509 \\ views of the DPT \\ webpage a month \\ with an average of \\ 2.03 minutes spent \\ on the site.
}

SPSS

Bivariate

There were no

significant

analysis differences in

Pearson's dementia literacy

Chi-squared between age

test groups, country or

Odds ratio gender. Sources of dementia

knowledge

included 'media'

(32.5\%),

'acquaintances'

(30.6\%), and

'workplace' (15.9\%)

with a minority

answering 'doctor'

(1.3\%). Despite the

majority of

respondents

having not heard

about dementia

from their doctor,

$81 \%$ would seek

help from a doctor

if thought they

had dementia.

One third of GPs

and two thirds of

PNs reported

lacking dementia

training. Just under

one quarter of GPs

and under one

fifth of PNs

considered their

dementia

knowledge

adequate. There

was no significant

relationship 
Table 7 Mixed Method studies. Characteristics of Mixed Methods studies reviewed (Continued)

\begin{tabular}{lllll}
\hline $\begin{array}{l}\text { Author, year, Aim } \\
\text { country }\end{array}$ Research design Instruments & $\begin{array}{l}\text { Sample and size } \\
\text { (+characteristics) })\end{array}$ & $\begin{array}{l}\text { Type and } \\
\text { description of } \\
\text { intervention }\end{array}$ & $\begin{array}{l}\text { Analysis method } \\
\text { Outcomes }\end{array}$
\end{tabular}

between training and adequacy of dementia knowledge.

Despite this lack of self-reported lack of dementia knowledge, two thirds of doctors and three quarters of PNs responded that a doctor or nurse was the appropriate person to discuss dementia with patients.

Perry et al., 2010 [34] Netherlands

To construct a set
of quality
indicators (QIs) for
dementia
diagnosis and
management in a
primary care
setting.

\begin{tabular}{|c|c|c|}
\hline $\begin{array}{l}\text { lliffe et al., } 2014 \\
\text { [35] } \\
\text { United } \\
\text { Kingdom } \\
\text { Supplementary } \\
\text { papers } \\
\text { Bamford et al., } \\
2014 \text { [36] } \\
\text { Iliffe et al., } 2014 \\
\text { [37] }\end{array}$ & $\begin{array}{l}\text { To adapt a US } \\
\text { model of primary } \\
\text { care-based case } \\
\text { management } \\
\text { (CM) (PREVENT) } \\
\text { for people with } \\
\text { dementia and } \\
\text { test it in General } \\
\text { Practice }\end{array}$ & $\begin{array}{l}\text { Mixed } \\
\text { methodology } \\
\text { comprising case } \\
\text { studies of CM } \\
\text { implementation } \\
\text { in four General } \\
\text { Practices } \\
\text { and Interview } \\
\text { with patients, } \\
\text { support person(s) }\end{array}$ \\
\hline
\end{tabular}

Postal survey GPs (67), PCNs (21)

RAND modified GPs and PCNs and informal careDelphi including a postal survey, stakeholders consensus meeting, a scientific expert consensus meeting and demonstration project assessed relevance, feasibility of givers (34).

Eight national dementia experts Qls (1 geriatrician, 2 Informal GPs, 2 nursing support scientists, 1 person(s) medical assessed sociologist, 1 relevance of Ql psychologist, 2 only Inclusion, exclusion, revision of Qls by consensus at stakeholder and scientific expert meetings Demonstration project tested adherence rates and discriminative validity.

\section{CAREDEM Case Participants were} management community dwelling patients with dementia who were living at home with a family support person(s) and who were not receiving specialist care
The CAREDEM intervention consisted of CM face to face training and mentoring based on an educational needs assessment, development of a learning manual
Cronbach The final set of 23 alpha Qls included 15 Intraclass Qls containing correlation innovative quality Mean criteria on scores and collaboration standard between GPs and deviations PCNs, referral ANOVA criteria and assessment of support person(s) needs. Several indicators explicitly describe collaboration between GPs and PCNs, an area in which

improvement is highly recommended. The Qls are reported as feasible, reliable and valid able to be used to improve primary dementia care.
Thematic This study analysis of suggested that CM data was does not fit easily synthesised into practice in an iterative process until consensus was routines and that it was not substantially beneficial for patients and support person(s) 
Table 7 Mixed Method studies. Characteristics of Mixed Methods studies reviewed (Continued)

\begin{tabular}{|c|c|c|c|c|c|c|c|}
\hline $\begin{array}{l}\text { Author, year, } \\
\text { country }\end{array}$ & Aim & Research design & Instruments & $\begin{array}{l}\text { Sample and size } \\
\text { (+characteristics) }\end{array}$ & $\begin{array}{l}\text { Type and } \\
\text { description of } \\
\text { intervention }\end{array}$ & $\begin{array}{l}\text { Analysis } \\
\text { method }\end{array}$ & Outcomes \\
\hline $\begin{array}{l}\text { Waugh et al., } \\
2013 \text { [38] }\end{array}$ & & $\begin{array}{l}\text { local NHS and } \\
\text { other } \\
\text { stakeholders, and } \\
\text { case managers }\end{array}$ & & $\begin{array}{l}\text { coordination. } \\
\text { A total of } 28 \text { dyads } \\
\text { and } 1 \text { support } \\
\text { person(s) were } \\
\text { recruited across } \\
\text { four practices; one } \\
\text { rural, one inner- } \\
\text { city and two } \\
\text { urban. }\end{array}$ & $\begin{array}{l}\text { that could be } \\
\text { shared between } \\
\text { CMs and patient- } \\
\text { support person(s) } \\
\text { dyads and } \\
\text { identification of } \\
\text { skills needed by } \\
\text { dementia CMs } \\
\text { working in } \\
\text { primary care. }\end{array}$ & reached & $\begin{array}{l}\text { despite CMs, } \\
\text { patients and } \\
\text { support person(s) } \\
\text { reporting a } \\
\text { positive experience } \\
\text { of CM. } \\
\text { Perceived benefits } \\
\text { of CM by the dyad } \\
\text { included having a } \\
\text { first point-of- } \\
\text { contact, a 'safety } \\
\text { net' and the } \\
\text { creation of a one- } \\
\text { to-one therapeutic } \\
\text { relationship. } \\
\text { CM perceived } \\
\text { advantages was } \\
\text { provision of } \\
\text { continuity of care } \\
\text { and flexibility of } \\
\text { responsiveness to } \\
\text { needs. } \\
\text { The NHS and } \\
\text { social care } \\
\text { professionals } \\
\text { perceived } \\
\text { advantages of CM } \\
\text { as continuity of } \\
\text { care, earlier } \\
\text { intervention and } \\
\text { that it was } \\
\text { complementary to } \\
\text { existing secondary } \\
\text { care and social } \\
\text { services. } \\
\text { All case managers } \\
\text { cited time } \\
\text { constraints as an } \\
\text { obstacle to } \\
\text { working with their } \\
\text { target group and } \\
\text { identified relatively } \\
\text { few concrete } \\
\text { benefits to } \\
\text { participating } \\
\text { patients and } \\
\text { support person(s). }\end{array}$ \\
\hline
\end{tabular}

and all but one of the mixed methods studies rated high according to the quality appraisal criteria. Of the quantitative studies two of the three RCT studies lacked allocation concealment, blinding and presented incomplete outcome data which compromised their quality. The survey studies were of mixed quality with two of the three studies introducing selection bias and no sample size was based on consideration of statistical power.

In addition to these limitations, Callahan et al., [18] describe their study as unable to identify which of the subcomponents of the intervention were most effective in achieving the outcomes. Van den Dungen et al., [15] reported the rates of $\mathrm{MCI}$ or dementia identified were lower than expected. The authors state the reasons for this may have included a type 2 error with a low sensitivity of the cognitive tests performed by PN. In addition, there was sub-optimal implementation of the intervention with the family practitioner not always performing further diagnostic assessments on all persons referred by the PN [15]. Thyrian et al., [19] describe limitations of the study including potential selection bias as screening and recruitment were part of routine care. The intervention and control groups had an uneven number of participants; the GPs in the control group had fewer patients. In addition, the GPs may have become aware of their assignment to the control or intervention group [19]. 
Table 8 Qualitative studies. Characteristics of the qualitative studies reviewed

\begin{tabular}{|c|c|c|c|c|c|}
\hline $\begin{array}{l}\text { Author, year, } \\
\text { country }\end{array}$ & Aim & $\begin{array}{l}\text { Research } \\
\text { design }\end{array}$ & Instruments & $\begin{array}{l}\text { Sample and size } \\
\text { (+characteristics) }\end{array}$ & $\begin{array}{l}\text { Type and } \\
\text { description of } \\
\text { intervention }\end{array}$ \\
\hline $\begin{array}{l}\text { Dodd et al., } \\
2014 \text { [39] } \\
\text { United } \\
\text { Kingdom }\end{array}$ & $\begin{array}{l}\text { To contrast } \\
\text { participant's } \\
\text { experiences of } \\
\text { primary care led } \\
\text { dementia } \\
\text { services in Bristol } \\
\text { with existing } \\
\text { secondary care } \\
\text { based memory } \\
\text { services }\end{array}$ & $\begin{array}{l}\text { Qualitative } \\
\text { participatory } \\
\text { study }\end{array}$ & $\begin{array}{l}\text { Semi-structured } \\
\text { interview. } \\
\text { Questions were } \\
\text { organised under } \\
\text { four main themes } \\
\text { (1) GPs making } \\
\text { an independent } \\
\text { dementia } \\
\text { diagnosis (2) GPs } \\
\text { working with } \\
\text { memory nurses } \\
\text { (3) patients and } \\
\text { support person(s) } \\
\text { experience, and } \\
\text { (4) post- } \\
\text { diagnostic } \\
\text { support. } \\
\text { The interviews } \\
\text { lasted, on } \\
\text { average, } 20 \\
\text { minutes. }\end{array}$ & $\begin{array}{l}\text { Purposive. } \\
\text { A total of } 23 \\
\text { participants (10 } \\
\text { health care } \\
\text { professionals, } 6 \\
\text { patients and } 7 \\
\text { support } \\
\text { person(s)). } \\
\text { Eligible patients } \\
\text { were people of } \\
\text { any age who had } \\
\text { been diagnosed } \\
\text { within the } \\
\text { previous six } \\
\text { months with any } \\
\text { form of dementia } \\
\text { (MCl excluded) } \\
\text { Participants were } \\
\text { recruited from GP } \\
\text { practices in Bristol } \\
\text { offering primary } \\
\text { care led dementia } \\
\text { services and } \\
\text { secondary care } \\
\text { health services } \\
\text { GPs were invited } \\
\text { by email to } \\
\text { participate in the } \\
\text { study. } \\
\text { Health care } \\
\text { professionals in } \\
\text { secondary care } \\
\text { were recruited } \\
\text { through team } \\
\text { meetings. }\end{array}$ & $\begin{array}{l}\text { A pilot model of } \\
\text { primary care led } \\
\text { dementia care } \\
\text { with three } \\
\text { memory nurses } \\
\text { seconded from } \\
\text { secondary care to } \\
\text { work within } \\
\text { primary care with } \\
\text { each memory } \\
\text { nurse providing } \\
\text { an advisory } \\
\text { service to a } \\
\text { group of } \\
\text { practices. } \\
\text { Participating GPs } \\
\text { attended a three- } \\
\text { hour training } \\
\text { session on } \\
\text { identifying, } \\
\text { assessing and } \\
\text { diagnosing } \\
\text { dementia. }\end{array}$ \\
\hline
\end{tabular}

Dodd et al., 2016 [41] United Kingdom

$\begin{array}{lll}\begin{array}{l}\text { To provide a } \\ \text { qualitative } \\ \text { analysis of the }\end{array} & \begin{array}{l}\text { Interview } \\ \text { Descriptive }\end{array} & \begin{array}{l}\text { Semi-structured } \\ \text { interview }\end{array} \\ \text { experiences of } \\ \text { health care } \\ \text { professionals, } \\ \text { patients and } \\ \text { their families, of } \\ \text { the new process } \\ \text { of assessment, } \\ \text { diagnosis and } \\ \text { treatment of } \\ \text { dementia within } \\ \text { a primary care } \\ \text { service. }\end{array}$

\section{3 surgeries in} the South Gloustershire Four patients, three care-givers and eight health care professionals were interviewed by peer researchers (caregivers).
Primary care led dementia service in which GPs led the process of assessment and establishing a diagnosis.

A memory nurse (from secondary

care) was available to support GPs and patients and support person(s) with diagnostic process.
Analysis method Outcome

$\begin{array}{ll}\text { Data coding and } & \text { Patients and } \\ \text { identifying } & \text { support person(s) } \\ \text { evidence that } & \text { were uniform in } \\ \text { related to each of } & \text { the praise of the } \\ \text { the four themes } & \text { work by memory }\end{array}$
from the panel nurses in both

meetings using a primary and prescribed secondary care process, settings. described by Many GPs did not Clarke [40].

feel confident to conduct a dementia assessment without involving a memory nurse and reported that they valued the working relationship with the memory nurse. Memory nurses found liaising with GPs to be cumbersome and time consuming. Patients and support person(s) perceived there was an absence of supporting patients through the assessment and post diagnostic support from GPs. Information came from memory nurses and other memory service staff or through the media.

Thematic analysis There were two using Braun and consistently Clarke [42] six- expressed phase model concerns by all groups of participants (1) lack of postdiagnostic COordination (2) GPled or multidisciplinary assessment without secondary care support. The advisory role of the memory nurse in the primary care service was valued by GPs. Referral to secondary care 
Table 8 Qualitative studies. Characteristics of the qualitative studies reviewed (Continued)

\begin{tabular}{llll}
\hline $\begin{array}{l}\text { Author, year, Aim } \\
\text { country }\end{array}$ & $\begin{array}{l}\text { Research Instruments } \\
\text { design }\end{array}$ & $\begin{array}{l}\text { Sample and size } \\
\text { (+characteristics) }\end{array}$ & $\begin{array}{l}\text { Type and } \\
\text { description of } \\
\text { intervention }\end{array}$
\end{tabular} Analysis method Outcome

\begin{tabular}{|c|c|c|c|c|c|c|}
\hline & & & & & & $\begin{array}{l}\text { memory nurses } \\
\text { who provided } \\
\text { specialised } \\
\text { assessment and } \\
\text { post-diagnostic } \\
\text { support, including } \\
\text { home visits, was } \\
\text { valued by } \\
\text { patients and } \\
\text { support person(s). }\end{array}$ \\
\hline $\begin{array}{l}\text { Manthorpe et } \\
\text { al., 2003 [43] } \\
\text { United } \\
\text { Kingdom } \\
\text { Supplementary } \\
\text { papers } \\
\text { lliffe et al., } 1999 \\
\text { [27] } \\
\text { lliffe et al., } 2003 \\
\text { [28] }\end{array}$ & $\begin{array}{l}\text { To explore the } \\
\text { implications of } \\
\text { the early } \\
\text { recognition of } \\
\text { dementia for } \\
\text { inter-professional } \\
\text { working. }\end{array}$ & $\begin{array}{l}\text { Focus group } \\
\text { interviews }\end{array}$ & $\begin{array}{l}\text { Nominal group } \\
\text { technique }\end{array}$ & $\begin{array}{l}\text { Convenience } \\
\text { sample. } \\
\text { Nearly } 1000 \text { GPs } \\
\text { (247), CMHNs } \\
\text { (79), practice (36) } \\
\text { and CNs (146), } \\
\text { social workers } \\
\text { and nursing } \\
\text { home staff took } \\
\text { part in four focus } \\
\text { groups in each of } \\
24 \text { multi- } \\
\text { disciplinary } \\
\text { workshops in the } \\
\text { UK. }\end{array}$ & $\begin{array}{l}\text { Thematic and } \\
\text { interpretative } \\
\text { analysis of data }\end{array}$ & $\begin{array}{l}\text { Four key bipolar } \\
\text { categories were } \\
\text { derived from the } \\
\text { workshops. (1) } \\
\text { opportunistic } \\
\text { versus population } \\
\text { screening (2) } \\
\text { referral and } \\
\text { responsibility (3) } \\
\text { key working and } \\
\text { team working (4) } \\
\text { generalist versus } \\
\text { specialist roles. } \\
\text { Nurses overall } \\
\text { were the } \\
\text { professional } \\
\text { group considered } \\
\text { to have the skills } \\
\text { and capacity in } \\
\text { dementia care } \\
\text { with CMHNs as } \\
\text { specialists who } \\
\text { may take on } \\
\text { long-term and } \\
\text { complex cases. } \\
\text { The PN was } \\
\text { identified as the } \\
\text { practitioner most } \\
\text { appropriate to } \\
\text { take on screening } \\
\text { for dementia and } \\
\text { monitoring. It was } \\
\text { reported that } \\
\text { screening by the } \\
\text { PN become a } \\
\text { core skill and } \\
\text { routine in primary } \\
\text { care. }\end{array}$ \\
\hline
\end{tabular}

Trickey et al., [11] describe a methodological limitation of using a vignette that may more correctly explore current practice rather than knowledge and attitudes [11]. Iliffe et al., [35] report time constraints for the case management role of the PNs may have meant there was insufficient time to show the potential of case management.

\section{Discussion}

This systematic review of the published literature, available in English, on the current and potential role of the $\mathrm{PN}$ in the delivery of care to people living with dementia or cognitive impairment and their support person(s) evaluated thirteen studies.

There has been no previous systematic reviews of the role or potential role for the PN in the delivery of care to people living with dementia or cognitive impairment and their support person(s). The results from this review are therefore novel and should be used to inform the role of the PN in the provision of dementia care and also future research on this topic.

The heterogeneity of studies' purpose, design, and outcomes measures make it difficult to synthesise the findings and draw conclusions. However, the heterogeneity did 


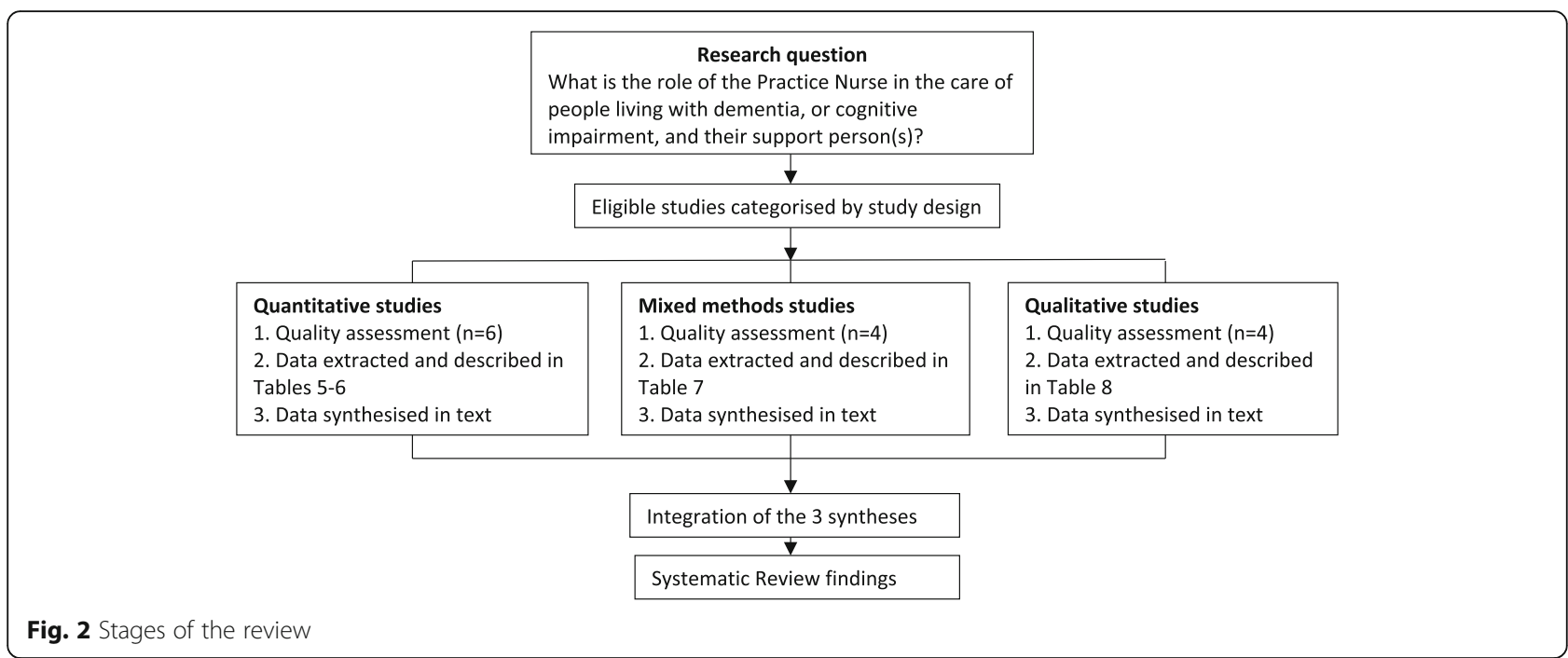

provide important insights into the different roles of nurses and advances understanding about the intervention itself rather than just its effectiveness. The only clearly defined role that was examined was that of the primary care based nurse as a care manager $[15,18,19,35]$. There were mixed findings regarding the effectiveness of the nurse-led care management model of care in improving quality of life measures for people living with dementia and their support person(s). However, no studies dismissed the potential of this model, with further research recommended. Callahan et al., [18] was assessed as the highest quality RCT study. The authors reported that a care management model of care can be implemented in primary care and that the effectiveness of the intervention depended on the key role of the nurse. All the nurses in these care management studies were registered nurses with dementia specific training, however in the Callahan et al., [18] study the care manager was a geriatric nurse practitioner. All health practitioners in the care manager studies described the experience as positive and perceived there to be benefits to the patient. Nurses did describe the role as time consuming and liaising with the primary care medical practitioner as cumbersome $[15,39]$. However, the care manager role was considered resource intensive, which could prove a challenge in its integration with practice routines that often operate, with limited time for consultations and budgetary constraints. The care management model described in Callahan et al., [18] was particularly resource intensive with one year of care management, weekly mentoring for the care manager, weekly then monthly patient contacts, and monthly care-giver support groups with concurrent exercise groups for the person living with dementia.

The other studies $[3,11,12,29,32,34,39,41,43]$ explored characteristics of the role of the primary care based nurse in the care of people living with dementia and the support person. These studies were of variable quality but consistent in their outcomes. The PN was described as having an increasing profile in primary health care and being more accessible to patients, partly as a result of their changing role to include chronic disease management. There was recognition of the $\mathrm{PN}$ as the appropriate professional to take on the role of screening for cognitive impairment and monitoring, with the medical practitioner being responsible for diagnosis. The $\mathrm{PN}$ is usually responsible for the Over 75 health check which is currently underutilised [11] and provides an opportunity to identify people with cognitive impairment. A common issue in the studies was the poor recording of diagnosis or outcome of cognitive testing in electronic medical records. Several studies identified that post-diagnostic support and carer support were lacking in current dementia care provision in primary health care $[29$, $35,39]$. Patients with memory concerns reported that they would welcome the opportunity to discuss dementia risk reduction with the GP however the GP was not meeting this need [3]. This responsibility was reported as potentially within the scope of the primary care nurse role [3].

Developing good working relationships with the medical practitioner, familiarity with the primary care setting, perception of autonomy, dementia specific education and the embedding dementia care provision in primary health care were seen as essential to the success of the primary care nurse in dementia care provision. A consistent finding across the studies was that primary care nurses reported a lack of confidence in dementia care provision and the rating of their knowledge and skills as inadequate. This is despite the perception that nurses include themselves as an appropriate professional to discuss dementia with a patient. The need for education and training was stressed in all studies as necessary for successful dementia care provision. The use of guidelines was perceived as valuable by nurses to improve knowledge and standardise practice. 
Nurses in the care management models used detailed standardised protocols for dementia care provision.

\section{Implications for practice and research}

There is justification for the involvement of the $\mathrm{PN}$ in the recognition and care of people living with dementia and their support person(s). However, there is little evidence on the scope of practice and framework of primary care nurse models of dementia care provision. The different studies examined different aspects of the PNs role in relation to dementia. Differences in scopes of nurse practice and health systems mean one model of care may not be appropriate. However this systematic review provides insights into what components of a model of care may be effective. These roles included care management, identification and/ or management of behavioural and psychological symptoms of dementia. Some nurses were seconded from secondary care memory clinics, some were registered nurses working in general practice and one was a geriatric nurse practitioner. Dementia training for the nurses also greatly varied across studies from several hours to months and the types of training differed in breadth and intensity.

More high quality studies are required to establish the scope of practice, effectiveness, cost implications and the applicability of the PN role in the care of people living with dementia, or cognitive impairment, and their support person(s) in general practice.

\section{Strengths and limitations}

This is the first systematic review to investigate the role of the PN in the care of people living with dementia, or cognitive impairment, and their support person(s) in general practice. An explicit, systematic methodology was followed to review the published peer-reviewed literature relevant to the topic. National and international literature was reviewed and the studies utilised a variety of methodologies including qualitative, quantitative and mixed methods. It was not possible to conduct a metaanalysis due to the heterogeneous nature of the interventions. The studies included in this review were published in English only and grey or white literature was not included. Some studies may not have been identified by the search terms used in each database.

\section{Conclusions}

The aim of this systematic review was to investigate the role of the PN in the care of people living with dementia, or cognitive impairment, and their support person(s) in general practice. The potential value of the $\mathrm{PN}$ in the recognition and management of dementia has been acknowledged. However, the findings of this review revealed that there is limited evidence on the role of the $\mathrm{PN}$ in dementia care provision. The strength of this review is the identification of benefits of roles fulfilled by nurses in the general practice setting for people living with dementia and their support person(s). These included increased patient accessibility to the PN, early recognition and management of cognitive changes, care management and collaboration with the GP. Limitations of the provision of dementia care by the PN included a lack of definition of the role, inadequate dementia specific training, time constraints and poor communication with GPs.

Models of dementia care provision with mechanisms to support the practice nurse role and the embedding of it into usual general practice care have the potential to increase early recognition of cognitive impairment and more appropriate primary care management of dementia.

\section{Abbreviations}

APNA: Australian primary health nurse association; CMHN: Community mental health nurse; CN: Community nurse; DCM: Dementia care management; FP: Family practitioner; GP: General practitioner; MMSE: Mini mental state examination; NHS: National health service; QOL: Quality of life; RCT: Randomised controlled trial

\section{Acknowledgements}

Not applicable.

\section{Authors' contributions}

CG, DG and DP developed the review question, designed the review and developed the search strategy. CG and DG conducted the selection, undertook the data extraction and conducted the quality assessment. DP helped resolve any discrepancies in the quality assessment. CG and DG wrote the manuscript and DP provided critical commentary on initial versions of the manuscript. All authors have read and approved the final submitted manuscript.

\section{Funding}

This research contributes to a larger program of work being conducted by the Australian Community of Practice in Research in Dementia (ACcORD), which is funded by a Dementia Research Team Grant from the National Health and Medical Research Council. Caroline Gibson is supported by a University of Newcastle Postgraduate Research Scholarship from the Faculty of Health and Medicine.

Availability of data and materials Not applicable.

Ethics approval and consent to participate Not applicable.

Consent for publication Not applicable.

\section{Competing interests}

The authors declared no conflicts of interest.

\section{Author details}

${ }^{1}$ Faculty of Health and Medicine, School of Medicine and Public Health, University of Newcastle, Callaghan, Australia. ${ }^{2}$ Central Clinical School, Monash University; Kolling Institute, the University of Sydney, Sydney, Australia. 
Received: 25 December 2019 Accepted: 28 May 2020 Published online: 13 July 2020

\section{References}

1. Koch T, lliffe S. Dementia diagnosis and management: a narrative review of changing practice. Br J Gen Pract. 2011. https://doi.org/10.3399/ bjp11X588493.

2. Strivens E, Craig D. Managing dementia - related cognitive decline in patients and their caregivers. Aust Fam Physician. 2014;43(4):170-4.

3. Millard FB, Kennedy RL, Baune BT. Dementia: Opportunities for risk reduction and early detection in general practice. Aust J Prim Health. 2011. https://doi.org/10.1071/PY10037.

4. Phillips J, Pond D, Goode S. Timely diagnosis of Dementia: Can we do better? A report for Alzheimers Australia. NSW: Alzheimer's Australia; 2011. p. 42. Paper 24.

5. Brown L, Hansnata E, Anh LH. Economic cost of dementia in Australia 20162056. Canberra: Institute for Governance and Policy Analysis; 2017. p. 66.

6. Valcour VG, Masaki KH, Curb JD, Blanchette PL. The detection of dementia in the primary care setting. Arch Intern Med. 2000 Oct;160(19):2964-8.

7. Young J, Eley D, Patterson E, Turner C. A nurse-led model of chronic disease management in general practice - patients' perspectives. Aust Fam Pract. 2016;45(12):912-6.

8. Bunn F, Burn A, Goodman C, Robinson L, Rait G, Norton S, et al. Comorbidity and dementia: a mixed-method study on improving health care for people with dementia (CoDem). Health Serv Delivery Res. 2016;4(8).

9. Randall S, Crawford T, Currie J, River J, Betihavas V. Impact of community based nurse-led clinics on patient outcomes, patient satisfaction, patient access and cost-effectiveness - a systematic review. Int J Nurs Stud. 2017;73: 24-33.

10. Ibrahim JE, Anderson LJ, MacPhail A, Lovell JJ, Davis M, Winbolt M. Chronic disease self-management support for persons with dementia in a clinical setting. J Multidiscip Healthc. 2017;10:49-58.

11. Trickey H, Turton P, Harvey I, Wilcock G, Sharp D. Dementia and the Over-75 Check: the role of the primary care nurse. Health Soc Care Commun. 2000; 8(1):9-16.

12. Manthorpe J, lliffe S, Eden A. Early recognition of dementia by nurses. J Adv Nurs. 2003:44(2):183-91.

13. Shamseer L, Moher D, Clarke M, Ghersi D, Liberati L, Petticrew M, et al. Preferred reporting items for systematic review and meta-analysis protocols (PRISMA-P). 2015: elaboration and explanation. BMJ. 2015. https://doi.org/10. 1136/bmj.g7647.

14. Liberati A, Altman D, Tetzlaff J, Mulrow C, Gotzsche P, loannidis JP, et al. The PRISMA statement for reporting systematic reviews and meta-analyses of studies that evaluate healthcare interventions: explanation and elaboration. Research Methods and Reporting. BMJ. 2009. https://doi.org/10.1136/bmj. b2700.

15. Van den Dungen $P$, Moll van Charante EP, van de Ven PM, van Marwijk HW, van der Horst HE, van Hout HPJ. Case Finding of Mild Cognitive Impairment and Dementia and Subsequent Care; Results of a Cluster RCT in Primary Care. PLoS One. 2016. https://doi.org/10.1371/journal.pone.0156958.

16. Perry M, Draskovic I, van Achterberg T, Borm G, van Eijken M, Lucassen $P$, et al. Can an EASYcare based dementia training programme improve diagnostic assessment and management of dementia by GPS and primary care nurses? The design of a randomised controlled trial. BMC Health Serv Res. 2008. https://doi.org/10.1186/1472-6963-8-71.

17. Van den Dungen $P$, Moll van Charante EP, van Marwijk HW, van der Horst $\mathrm{HE}$, van de Ven PM, van Hout HP. Case-finding of dementia in general practice and effects of subsequent collaborative care; design of a cluster RCT. BMC Public Health. 2012;12:609.

18. Callahan CM, Boustani MA, Unverzagt FW, Austrom MG, Damush TM, Perkins AJ, et al. Effectiveness of collaborative care for older adults with Alzheimer disease in primary care: A randomized controlled trial. JAMA. 2006. https://doi.org/10.1001/jama.295.18.2148.

19. Thyrian JR, Hertel J, Wucherer D, Eichler T, Michalowsky B, DreierWolfgramm A, et al. Effectiveness and Safety of Dementia Care Management in Primary Care: A Randomized Clinical Trial. JAMA Psychiatry. 2017. https://doi.org/10.1001/jamapsychiatry.2017.2124.

20. Drier A, Thyrian JR, Eichler T, Hoffman W. Qualifications for nurses for the care of patients with dementia and support to their caregivers: A pilot evaluation of the dementia care management curriculum. Nurse Educ Today. 2016. https://doi.org/10.1016/j.nedt.2015.07.024.
21. Thyrian JA, Fib T, Dreier A, Bowing G, Angel A, Lueke S, et al. Life- and person-centred help in Mecklenburg - Western Pomerania, Germany (DelpHi): study protocol for a randomised controlled trial. Trials. 2013;13:56.

22. Austrom MG, Hartwell C, Moore PS, Boustani M, Hendrie HC, Callahan CM. A care management model for enhancing physician practice for Alzheimer disease in primary care. Clin Gerontol. 2005. https://doi.org/10.1300/ J018v29n0205.

23. Austrom MG, Hartwell C, Moore P, Perkins AJ, Damush T, Unverzagt FW, et al. An integrated model of comprehensive care for people with Alzheimer's disease and their caregivers in a primary care setting. Dementia. 2006;5(3): 339-52.

24. Austrom MG, Damush TM, Hartwell CW, Perkins T, Unverzagt FW, Boustani $M$, et al. Development and Implementation of Nonpharmacological Protocols for the Management of Patients with Alzheimer's Disease and their Families in a Multiracial Primary Care Setting. Gerontologist. 2004;44(4): 548-53.

25. Boustani M, Callahan CM, Unverzagt FW, Austrom MG, Perkins AJ, Fultz BA, et al. Implementing a Screening and Diagnosis Program for Demenia in Primary Care. J Gen Intern Med. 2005. https://doi.org/10.1111/j.1525-1497. 2005.0126.x

26. Downs M, Rae C. General practitioners' approach to establishing and communicating a diagnosis of dementia. In: Annual Conference of the British Society of Gerontology, Liverpool University; 1996.

27. Iliffe S, Eden A, Downs M, Rae C. The diagnosis and management of dementia in primary care: development, implementation and evaluation of a national training program. Aging Ment Health. 1999;3(2):129-35.

28. Iliffe S, Manthorpe J, Eden A. Sooner or later? Issues in the early diagnosis of dementia in general practice: A qualitative study. Fam Pract. 2003. https:// doi.org/10.1093/fampra/cmg407.

29. Gilbert C, Wilcock J, Thuné-Boyle I, lliffe S. A comparison of service use by people with dementia in two samples a decade apart. Dementia. 2017;2017. https://doi.org/10.1177/1471301215581504.

30. Downs M, Turner S, Bryans M, Wilcock J, Keady J, Leven E, et al. Effectiveness of educational interventions in improving detection and management of dementia in primary care: cluster randomised controlled study. BMJ. 2006;332:692.

31. Iliffe S, Wilcock J, Griffin M, Jain P, Thune-Boyle I, Koch T, et al. Evidencebased interventions in dementia: A pragmatic cluster-randomised trial of an educational intervention to promote earlier recognition and response to dementia in primary care (EVIDEM-ED). Trials. 2010;11:13.

32. Ollerenshaw A, Wong Shee A, Yates M. Towards good dementia care: Awareness and uptake of an online Dementia Pathways tool for rural and regional primary health practitioners. Aust J Rural Health. 2017. https://doi. org/10.1111/ajr.12376.

33. Millard FB, Baune BT. Dementia - who cares? A comparison of community needs and primary care services. Aust Fam Physician. 2009;38(6):642-9.

34. Perry M, Draskovic I, Van Achterberg T, Van Eijken M, Lucassen P, VernooijDassen $M$, et al. Development and validation of quality indicators for dementia diagnosis and management in a primary care setting. J Am Geriatr Soc. 2010. https://doi.org/10.1111/j.1532-5415.2010.02726.x.

35. Niffe S, Robinson L, Bamford C, Waugh A, Fox C, Livingston G, et al. Introducing case management for people with dementia in primary care: a mixed-methods study. Br J Gen Pract. 2014. https://doi.org/10.3399/ bjgp14X682333.

36. Bamford C, Poole M, Brittain K, Chew-Graham C, Fox C, lliffe S, et al. Understanding the challenges to implementing case management for people with dementia in primary care in England: a qualitative study using Normalization Process Theory. BMC Health Serv Res. 2014;14:549.

37. Niffe S, Waugh A, Poole M, Bamford C, Brittain K, Chew-Graham C, et al. The effectiveness of collaborative care for people with memory problems in primary care: Results of the CAREDEM case management modelling and feasibility study. Health Technol Assess. 2014. https://doi.org/10.3310/hta18520.

38. Waugh A, Austin A, Manthorpe J, Fox C, Stephens B, Robinson L, Iliffe S. Designing a complex intervention for dementia case management in primary care. BMC Fam Pract. 2013;14:101.

39. Dodd E, Cheston R, Fear T, Brown E, Fox C, Morley C, et al. An evaluation of primary care led dementia diagnostic services in Bristol. BMC Health Serv Res. 2014. https://doi.org/10.1186/s12913-014-0592-3.

40. Clarke JP. How to peer review a qualitative manuscript. In: Godlee F, Jefferson T, editors. Peer Review in Health Sciences. 2nd ed. London: BMJ Books; 2003. p. 219-35. 
41. Dodd E, Cheston R, Cullum S, Jefferies R, Ismail K, Gatting L, et al. Primary care-led dementia diagnosis services in South Gloustershire: Themes from people and families living with dementia and health care professionals. Dementia. 2016. https://doi.org/10.1177/1471301214566476.

42. Braun V, Clarke V. Using thematic analysis in psychology. Qual Res Psychol. 2006;3(2):77-101.

43. Manthorpe J, lliffe S, Eden A. The implications of the early recognition of dementia for multiprofessional teamworking. Dementia. 2003;2(2):163-79.

44. Higgins JPT, Altman DG, Gotzsche PC, Juni P, Moher D, Oxman AD, et al. The Cochrane Collaboration's tool for assessing risk of bias in randomised trials. BMJ. 2011. https://doi.org/10.1136/bmj.d5928.

45. CEBMa. Critical Appraisal of a Survey. In: Crombie, The Pocket Guide to Critical Appraisal: the critical appraisal approach used by the Oxford Centre for Evidence Medicine, checklists of the Dutch Cochrane Centre, BMJ editor's checklists of the EPPI Centre. 2018. Available at: https://www.cebma. org/wp-content/uploads/Critical-Appraisal-Questions-for-a-Survey.pdf. Accessed 14 Jul 2019.

46. Hong Q, Pluye P, Fabregues S, Bartlett G, Boardman F, Cargo M, et al. Mixed Methods Appraisal Tool (MMAT). User Guide. Canada: Canadian Intellectual Property Office, Industry Canada; 2018.

47. Critical Appraisal Skills Programme. CASP Qualitative Checklist. UK: Oxford. 2018. Available from: https://casp-uk.net/wp-content/uploads/2018/01/ CASP-Qualitative-Checklist-2018.pdf. .

48. Goeman D, Renehan E, Koch S. What is the effectiveness of the support worker role for people with dementia and their carers? A systematic review. BMC Health Serv Res. 2016. https://doi.org/10.1186/s12913-016-1531-2.

49. Thomas J, Harden A, Oakley A, Oliver S, Suttcliffe K, Rees R, et al. Integrating qualitative research with trials in systematic reviews. BMJ. 2004;328:7447.

50. Bryans M, Keady J, Turner S, Wilcock J, Down M, lliffe S. An exploratory study into primary care nurses and dementia care. Brit J Nurs. 2003;12(17): 1029-37.

\section{Publisher's Note}

Springer Nature remains neutral with regard to jurisdictional claims in published maps and institutional affiliations.

Ready to submit your research? Choose BMC and benefit from:

- fast, convenient online submission

- thorough peer review by experienced researchers in your field

- rapid publication on acceptance

- support for research data, including large and complex data types

- gold Open Access which fosters wider collaboration and increased citations

- maximum visibility for your research: over $100 \mathrm{M}$ website views per year

At $\mathrm{BMC}$, research is always in progress.

Learn more biomedcentral.com/submissions 